\title{
KAJIAN PENGEMBANGAN EKOWISATA MANGROVE BERBASIS MASYARAKAT DI DESA POREANG KECAMATAN TANALILI KABUPATEN LUWU UTARA
}

\author{
(Study of Community-Based Mangrove Ecotourism Development in Poreang \\ Village, Tanalili District, North Luwu Regency) \\ Handri Suting'), Hamsiah' ${ }^{2)}$, Danial' ${ }^{2)}$ \\ 1) Dinas Pengelolaan Keuangan Aset Daerah Kabupaten Luwu Utara \\ 2) Progarm Studi Manajamen Pesisir \& Teknologi Kelautan, PPS UMI Makassar
}

Korespondensi: $\underline{\text { sutinghandri@gmail.com }}$

Diterima: tanggal 5 Juli 2020; Disetujui 25 Agustus 2020

\section{ABSTRACT}

The mangrove forest community has a unique and important role. Mangrove forests are very vulnerable to damage if the environment is not balanced, even the destruction of mangroves is not only caused by natural processes, but also due to human activities, it needs direction and solutions in sustainable mangrove management. One of the efforts made in sustainable marine management is the development of community-based mangrove tourism potential. The purpose of this research (1) Evaluate social, economic and ecological empowerment, (2) Determine community empowerment strategies through mangrove ecotourism. Data collection instruments were carried out using questionnaires and field observation, then analyzed descriptively and then analyzed using a SWOT analyst. Based on the research conducted, it is found that the achievements of social, economic and ecological empowerment in the tourism area have not been achieved. And to achieve this success there are 3 strategic directions that are carried out in the development of community-based ecotourism (1) Development of community-based mangrove ecotourism with the assistance of institutions and government (2) Conduct training and development of local products and community skills to support mangrove forest ecotourism (3) Increasing socialization and community involvement in planning

Keywords: Community-Based; Mangrove; Ecotourism; Development; North Luwu Regency.

\section{ABSTRAK}

Komunitas hutan mangrove memiliki peranan yang unik dan penting, Hutan mangrove sangat rentan terhadap kerusakan jika lingkungan tidak seimbang. bahkan rusaknya mangrove bukan saja diakibatkan oleh proses alami, tetapi juga akibat aktivitas manusia, olehnya itu perlu arahan dan solusi dalam pengelolaan mangrove berkelanjutan. Salah satu upaya yang dilakukan dalam pengelolaan kelautan berkelanjutan adalah pengembangan potensi wisata mangrove berbasis masyarakat. Penelitian ini bertujuan (1) Mengevaluasi pemberdayaan sosial, ekonomi dan ekologi (2) Menentukan strategi pemberdayaan masyarakat melalui ekowisata mangrove. Instrumen pengumpulan data dilakukan dengan menggunakan kuisioner dan pengamatan lapang kemudian di analissis secara deskriptif dan selanjutnya di analisis dengan menggunakan analis SWOT. Berdasarkan penelitian yang dilakukan didapatkan capaian pemberdayaan sosial, ekonomi dan pemberdayaan ekologi dikawasan wisata belum tercapai. Dan untuk mencapai keberhasilan tersebut ada 3 arahan strategi yang dalam dilakukan dalam pengembangan ekowisata berbasis masyarakat (1), Pengembangan ekowisata mangrove berbasis masyarakat dengan pendampingan lembaga dan pemerintah, (2) Melakukan pelatihan dan pengembangan produk lokal serta keterampilan masyarakat untuk mendukung ekowisata hutan mangrove (3) Meningkatkan sosialisasi dan keterlibatan masyarakat dalam perencanaan

Kata kunci: berbasis masyarakat; ekowisata; mangrove; pengembangan; Kab.Luwu Utara 


\section{PENDAHULUAN}

Indonesia sebagai kepulauan (archipelagic country) terdiri dari pulau-pulau besar dan kecil yang jumlahnya kurang lebih 17.504 pulau, tiga perempat Wilayahnya adalah laut (5,9 juta $\mathrm{km} 2)$, dengan panjang garis pantai $95.161 \mathrm{~km}$, terpanjang kedua setelah Kanada (Lasabuda, 2013). Selain itu juga memiliki kekayaan sumber daya alam yang sangat potensial untuk pembangunan ekonomi karena memiliki daya dukung ekosistem dengan produktivitas hayati yang tinggi salah satunya adalah hutan mangrove

Hutan mangrove sangat rentan terhadap kerusakan jika lingkungan tidak seimbang. Bahkan rusaknya mangrove bukan saja diakibatkan oleh proses alami, tetapi juga akibat aktivitas manusia (Pramudji, 2000). Untuk mengantisipasi dampak negatif terjadi diperlukan suatu strategi kebijakan pengelolaan yang tepat dengan menerapkan prinsip-prinsip pengelolaan dan pemanfaatan sumber daya alam yang berwawasan ekologis dengan tetap memperoleh manfaat ekonomisnya secara berkelanjutan. Salah satu pengelelolaan yang dianggap efektif saat ini adalah dengan pengembangan ekowisata mangrove.

Kabupaten luwu utara memiliki garis pantai sepanjang $52,5 \mathrm{~km}$ dengan Luas hutan mangrove sebesar 7.926,91 ha. Desa Poreang merupakan salah satu desa di Kabupaten Luwu Utara yang memiliki luas mangrove mangrove sebesar $177 \mathrm{Ha}$ yang sangat potensial untuk dikembangkan sebagai kawasan ekowisata mangrove. Keberhasilan program tersebut tidak lepas dari peran dan pemberdayaan masyarakat. Pengembangan parawisata dan pemberdayaan masyarakat adalah bagian dari kesejahteraan masyarakat (Sutawa, 2012 dalam Azhani et al., 2019).

Penelitian ini bertujuan untuk menganalisis sejauh mana keberhasilan pemberdayaan masyarakat yang meliputi 3 aspek pemberdayaan yaitu pemberdayaan sosial, ekonomi dan ekologi dan menganalisis strategi yang tepat dalam pengembangan ekowista di Desa Poreang Kecamatan Tanalili.

\section{METODE PENELITIAN}

Penelitian ini dilaksanakan mulai tanggal 1 Maret 2020 - 20 Mei 2020. Pengambilan data di lakukan di Desa 
Poreang Kecamatan Tanalili Kabupaten Luwu Utara.

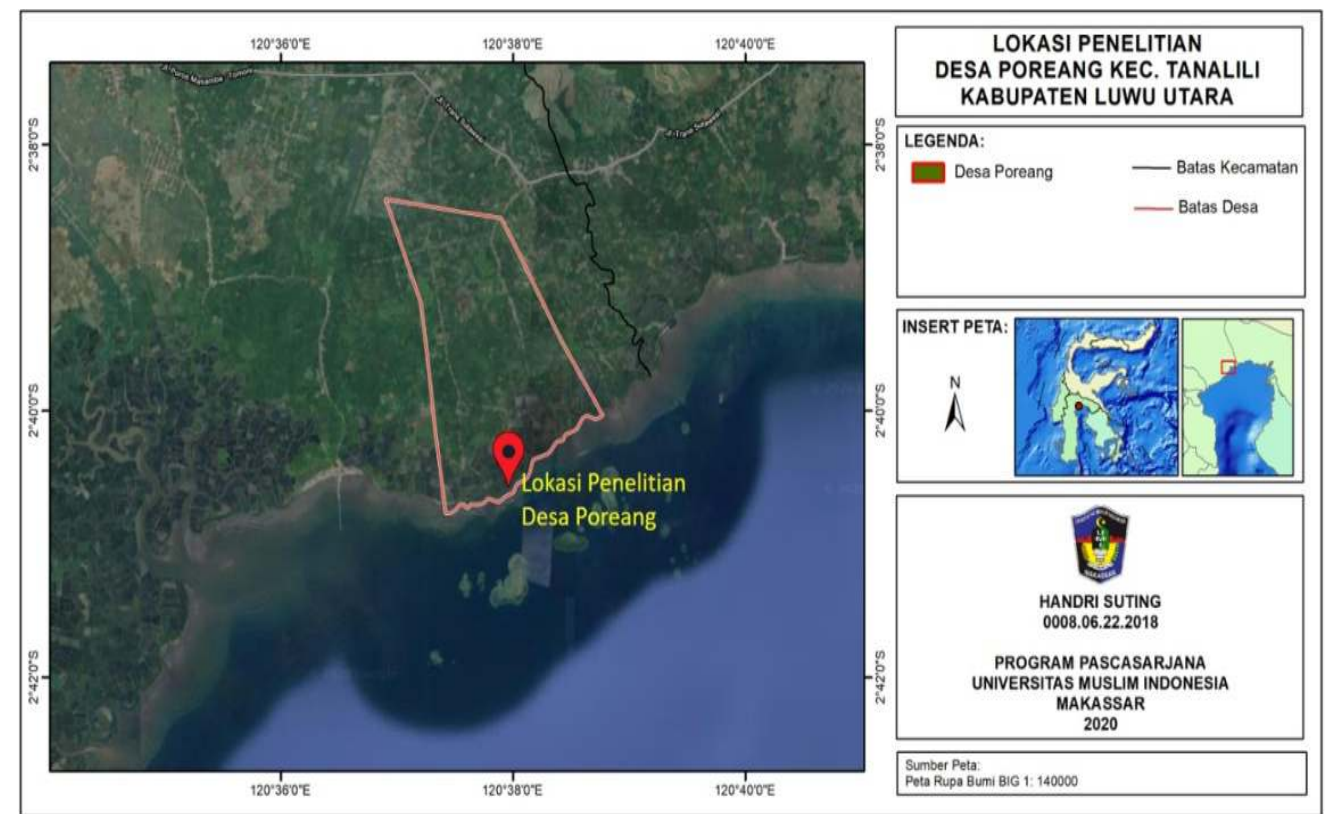

Gambar 1. Lokasi Penelitian

Secara umum teknik capaian indikator yang ditetapkan oleh pengumpulan data yang digunakan Winkler., 2012. Hasil wawancara akan dalam enelitian ini adalah teknik di lanjutkan dengan menggunakan observasi lapangan, wawancara, dan analisis SWOT. Analisis SWOT adalah pengumpulan data sekunder suatu cara mengidentifikasi berbagai (pendekatan triangulasi). Pengumpulan faktor secara sistematis dalam rangka data dilakukan dengan wawancara merumuskan strategi (Salatan et al., langsung menggunakan kuesioner 2018)

Teknik. sampling yang digunakan HASIL DAN PEMBAHASAN

untuk mengkaji pemberdayaan 1. Pemberdayaan Sosial

masyarakat ini adalah teknik terpilih Indikator pemberdayaan sosial (purposive sampling) dimana sampel menurut Winkler (2012) ada dua yaitu ditentukan atau dipilih sesuai dengan peningkatan kualifikasi diri dan kriteria yang ada. Metode analisis yang partisipasi masyarakat dalam ekowisata digunakan dalam penelitian ini adalah mangrove. Hasil capaian kedua metode analisis deskripsi dan untuk indikator tersebut dapat dilihat pada menentukan capaian dalam tabel 1.

pemberdayaan menggunakan skala 
Tabel 1. Capaian pemberdayaan sosial di kawasan wisata mangrove Desa Poreang Kecamatan Tanalili Kabupaten Luwu Utara

\begin{tabular}{|c|c|c|c|}
\hline Indikator & $\begin{array}{c}\text { Pengertian } \\
\text { (Winkler 2012) }\end{array}$ & Kondisi Masyarakat & Capaian \\
\hline $\begin{array}{l}\text { Peningkatan } \\
\text { Kualifikasi Diri }\end{array}$ & \begin{tabular}{l|} 
Kemampuan \\
masyarakat untuk \\
memperoleh keahlian \\
melalui pendidikan \\
sehingga dapat \\
memecahkan masalah \\
yang dihadapi, \\
meningkatkan inisiatif \\
untuk melalukan \\
konservasi lingkungan, \\
dan dapat memberikan \\
konstribusi dalam \\
peningkatan kesetaraan \\
dan kesejahteraan
\end{tabular} & $\begin{array}{l}\text { Hasil kuisioner diperoleh } \\
100 \% \text { masyarakat belum } \\
\text { mendapatkan pelatihan } \\
\text { peningkatan dan } \\
\text { pengembangan diri termasuk } \\
\text { pelatihan pengolahan produk } \\
\text { berbahan dasar mangrove } \\
\text { dalam usaha kepariwisataan } \\
\text { sehingga belum mampu } \\
\text { menjadikan peluang usaha } \\
\text { baru yang dapat membangun } \\
\text { inisiatif kemampuan dirinya } \\
\text { secara mandiri dalam } \\
\text { memperoleh kesejahteraan }\end{array}$ & $\begin{array}{l}\text { Belum } \\
\text { tercapai }\end{array}$ \\
\hline $\begin{array}{l}\text { Partisipasi } \\
\text { Masyarakat }\end{array}$ & $\begin{array}{l}\text { Kemampuan } \\
\text { masyarakat untuk } \\
\text { mempengaruhi hasil } \\
\text { akhir dari proyek } \\
\text { ekowisata melalui } \\
\text { perencanaan, } \\
\text { pengelolaan dan } \\
\text { pengembangan yang } \\
\text { dipercayakan kepada } \\
\text { mereka untuk } \\
\text { mencapai keberlanjutan } \\
\end{array}$ & $\begin{array}{l}\text { Masyarakat belum } \\
\text { berpartisipasi langsung dalam } \\
\text { pengelolaan ekowisata } \\
\text { mangrove, dapat dilihat pada } \\
\text { kuisioner bahwasanya } \\
\text { masyarakat belum terlibat } \\
\text { dalam hal promosi, } \\
\text { pengelolaan sarana dan } \\
\text { prasarana serta keamanan } \\
\text { kawasan. Hal ini disebabkan } \\
\text { karena lembaga pengelolah } \\
\text { kawasan wisata tersebut } \\
\text { belum terbentuk sehingga } \\
\text { dalam perencanaan sampai } \\
\text { pengelolaan, masyarakat } \\
\text { setempat belum terlibat }\end{array}$ & $\begin{array}{l}\text { Belum } \\
\text { tercapai }\end{array}$ \\
\hline
\end{tabular}


2. Pemberdayaan Ekonomi

Keberhasilan

pemberdayaan

Berdasarkan hasil penelitian yang peningkatan pendapatan masyarakat.

Tabel 2. Capaian pemberdayaan ekonomi di kawasan wisata mangrove Desa Poreang Kecamatan Tanalili Kabupaten Luwu Utara.

\begin{tabular}{|c|c|c|c|}
\hline Indikator & $\begin{array}{c}\text { Pengertian } \\
\text { (Winkler 2012) }\end{array}$ & Kondisi Masyarakat & Capaian \\
\hline $\begin{array}{l}\text { Peningkatan } \\
\text { Pendapatan }\end{array}$ & $\begin{array}{l}\text { Kemampuan } \\
\text { menciptakan lapangan } \\
\text { kerja baru dan } \\
\text { mendapatkan } \\
\text { keuntungan dari } \\
\text { ekowisata secara } \\
\text { merata untuk } \\
\text { mencegah terjadinya } \\
\text { konflik serta tetap } \\
\text { mempertahankan } \\
\text { keberlanjutan } \\
\text { lingkungan }\end{array}$ & $\begin{array}{l}\text { Masyarakat belum } \\
\text { menangkap peluang usaha } \\
\text { dan kerja baru dengan } \\
\text { adanya kawasan wisata } \\
\text { mangrove. Ini terlihat dari } \\
\text { kuisioner yang menunjukkan } \\
90,91 \% \text { responden tidak } \\
\text { menggunakan kawasan } \\
\text { wisata mangrove untuk } \\
\text { meningkatkan kesempatan } \\
\text { kerja. Peningkatan } \\
\text { kesempatan kerja akan } \\
\text { berbanding lurus dengan } \\
\text { peningkatan pendapatan. } \\
\text { karena masyarakat belum } \\
\text { dapat meningkatkan } \\
\text { kesempatan kerja maka } \\
\text { pendapatan msayarakat dari } \\
\text { aktifitas wisatapun belum } \\
\text { dapat meningkat }\end{array}$ & $\begin{array}{l}\text { Belum } \\
\text { tercapai }\end{array}$ \\
\hline
\end{tabular}

\section{Pemberdayaan Ekologi}

Konsep ekowisata

merupakan bentuk pengelolaan

sumberdaya pesisir dan laut yang sumberdaya menurut Winkler (2012)

dikembangkan dengan pendekatan dalam Azhani et al.(2019). Capaian konservasi (Ketjulan et al.,2013). Salah pemberdayaan ekologi dapat dilihat satu keberhasilan ekowisata adalah pada tabel 3. tercapainya pemberdayaan ekologi.

Untuk melihat keberhasilan

pemberdayaan ekologi dapat diukur dengan indikator adanya efisiensi 
Tabel 3. Capaian pemberdayaan ekologi di kawasan wisata mangrove Desa Poreang Kecamatan Tanalili Kabupaten Luwu Utara.

\begin{tabular}{|c|c|c|c|}
\hline Indikator & $\begin{array}{c}\text { Pengertian } \\
\text { (Winkler 2012) }\end{array}$ & Kondisi Masyarakat & Capaian \\
\hline $\begin{array}{l}\text { Efisiensi } \\
\text { sumberdaya }\end{array}$ & $\begin{array}{l}\text { Kemampuan } \\
\text { masyarakat lokal } \\
\text { untuk meningkatkan } \\
\text { penggunaan } \\
\text { sumberdaya } \\
\text { terbarukan dan } \\
\text { peningkatan kesadaran } \\
\text { terhadap keberlanjutan } \\
\text { lingkungan melalui } \\
\text { penghematan } \\
\text { penggunaan energi }\end{array}$ & $\begin{array}{l}\text { Mayarakat belum mampu } \\
\text { melakukan penghematan } \\
\text { energi sebagai contoh } \\
\text { melalui pengolahan daur } \\
\text { ulang sampah. Masyarakat } \\
\text { hanya sebatas menjaga } \\
\text { kebersihan kawasan wisata } \\
\text { mangrove tetapi belum } \\
\text { memiliki inisiatif untuk } \\
\text { menggunakan sumberdaya } \\
\text { yang ada menjadi } \\
\text { sumberdaya terbarukan }\end{array}$ & $\begin{array}{l}\text { Belum } \\
\text { tercapai }\end{array}$ \\
\hline
\end{tabular}

\section{Strategi Pengembangan}

\section{Ekowisata Mangrove}

Arahan

pengembangan

ekowisata mangrove di susun

berdasarkan atau mempertimbangkan

dimensi pembangunan berkelanjutan

(ekologi, ekonomi, sosial, budaya dan

kelembagaan). Untuk mengarahkan strategi pengembangan ekowisata mangrove di kawasan tersebut berdasarkan input ekologis, social, budaya dan ekonomi, maka dilakukan analisis dengan menggunakan analisis SWOT (Strength, Weakness, Opportunity, Threat). Tahap awal dari analisis SWOT dalam menentukan strategi adalah menaksir kekuatan, kelemahan, kesempatan dan ancaman yang dimiliki (Rangkuni., 2013)

Strategi pengembangan ekowista mangrove dihasilkan dari keterkaitan faktor interal (IFAS) dan faktor eksternal (EFAS). Berdasarkan hasil analisis matriks keterkaitan unsur SWOT tersebut maka dirumuskan 3 strategi dalam pengembangan ekowisata mangrove di Desa Poreang Kecamatan Tanalili Kabupaten Luwu Utara yaitu :

1. Pengembangan ekowisata mangrove berbasis masyarakat dengan pendampingan lembaga dan pemerintah,

2. Melakukan pelatihan dan pengembangan produk lokal serta 
keterampilan masyarakat untuk masyarakat dalam proses mendukung ekowisata hutan pemberdayaan agar hasil akhir dari mangrove tujuan pemberdayaan dapat tercapai,

3. Meningkatkan sosialisasi dan olehnya itu diharapkan program keterlibatan masyarakat dalam kegiatan terkait dengan pemberdayaan perencanaan masyarakat menjadi program prioritas

\section{KESIMPULAN}

Berdasarkan hasil pembahasan yang dilakukan dirumuskan kesimpulan sebagai berikut:

1. Pemberdayaan masyarakat baik pemberdayaan sosial, pemberdayaan ekonomi dan pemberdayaan ekologi belum tercapai.

2. Pemberdayaan masyarakat di rumuskan 3 strategi pemberdayaan yang dapat dilakukan yaitu (a) Pengembangan ekowisata mangrove berbasis masyarakat dengan pendampingan lembaga dan pemerintah (b) Melakukan pelatihan dan pengembangan produk lokal serta keterampilan masyarakat untuk mendukung ekowisata hutan mangrove (c) Meningkatkan sosialisasi dan keterlibatan masyarakat dalam perencanaan

\section{SARAN}

Dibutuhkan keterlibatan semua pihak baik pemerintah maupun bagi pemerintah.

\section{UCAPAN TERIMAKASIH}

Naskah jurnal ini merupakan bagian dari penelitian tesis dan penulis mengucapkan terima kasih kepada Pembimbing dan Ketua Prodi Manajemen Pesisir dan Teknologi Kelautan serta semua pihak atas bantuan yang diberikan sehingga jurnal ini dapat diselesaikan.

\section{DAFTAR PUSTAKA}

Azhani, P., Thayib, M.H. dan Alikodra, H.S. 2019. Pemberdayaan Masyarakat Melalui Ekowisata Mangrove (Suatu Kajian di Kawasan Hutan Mangrove Wonorejo, Kecamatan Rungkut, Pantai Timur Surabaya). Jurnal Bumi Lestari, Volume 19, Nomor 1: 20-27

Ketjulan, Romy, Arip B. dan Ahmad M. 2013. Kajian Potensi dan Kesesuaian Ekosistem Terumbu Karang di Pulau Lura Untuk Pengembangan Ekowisata Bahari. Jurnal Mina Laut

Lasabuda, R. 2013. Tinjauan Teoritis Pembangunan Wilayah Pesisir Dan Lautan Dalam Perspektif Negara Kepulauan Republik 
Indonesia . Jurnal Ilmiah Platax, Vol. I-2 : 92-101.

Pramudji. 2000. Dampak perilaku manusia pada ekosistem hutan mangrove di Indonesia. In publish

Salatan, S., Victoria E.N., dan Suriah D. 2018. Strategi Pemberdayaan Masyarakat Nelayan Soma Pajeko di Kecamatan Salibabu. Kota Kepulauan Talaud. Universitas Samratulangi

Shamdiyah, N. 2017. Analisis SWOT Strategi Pemberdayaan
Masyarakat Program Penataan Lingkungan Permukiman Komunitas di Kelurahan Suryatumajan Kota Yogyakarta. Agrifo. Universitas Malikussaleh. Aceh

Winkler, M. T. (2012). Ecotourism as Community Development Tool: Development of an Evaluation Framework. Master Thesis. Graz, Austria: Department of Geography and Regional Science, University of Graz 